\title{
Seawater Biorefinery of Avicennia Marina -Biomethane Potential at Seawater Conditions
}

\author{
S. Almardeai, U. Javid, J.R.BBastidas-Oyanedel, and J.E. Schmidt*
}

Masdar Institute of Science and Technology Institute Center for Energy-iEnergy, PO Box 54224, Abu Dhabi, UAE

\begin{abstract}
Lignocellulose is considered as an abundant source of carbohydrates that can be used to produce renewable fuels and chemicals such as biomethane, which have economic and environmental advantages over fossil resources. However, conventional bioprocesses are based on the use of fresh water. Finding a new way to minimize the need for fresh water is economically important. This study focuses on the feasibility of bioenergy production from local mangroves plant using sea water biorefinery concept. Samples of Avicennia marina were collected from the coastal areas in Ras Al Khaimah, United Arab Emirates. Based on anaerobic fermentation, inoculum was added to batch system that had sea water and the sampled biomass of $1.09 \mathrm{~g}$. Gas chromatography analysis had showed an increment in the biomethane production over an incubation period of initially of forty eight days at $37 \mathrm{C}$ and the last and highest reading reached $52.8 \mathrm{mlCH} 4 / \mathrm{gVS}$ by day 48 .
\end{abstract}

Keywords: Seawater, Biorefinery, Anaerobic Digestion, Biomethane Potential.

\section{Introduction}

The need for an alternative to fossil fuels has raised the interest for renewable energies and biomass conversion as one of the good options. For instance, controlled forestry of Mangroves, such as Avicennia marina, can be used as a biomass for the production of biofuels, chemicals and biogas. It is estimated to occupy 15.2 million hectares worldwide and it sustains and grow in very harsh conditions such as high temperature and high salinity (Sandilyan \& Kathiresan, 2012), such as in UAE in which the temperature is very high which is usually around $50^{\circ} \mathrm{C}$ in summer (Dodd, Blasco, Rafii, \& Torquebiau, 1999), and high salinity of the seawater which is around $43.2 \mathrm{~g} / \mathrm{kg}$ in comparison to the standard value which is $35 \mathrm{~g} / \mathrm{kg}$ (Millero, Feistel, Wright, \& McDougall, 2008).

However, the cost of these biorefineries is one of the drawbacks that held this type of energy to dominate. Most of the biorefineries are based on desalinated seawater which is energy intensive and cost money. Per each cubic meter of desalinating seawater between 3.5 to $5 \mathrm{kWh}$ is being used and 50 to 70 percentage of the desalination cost is going for energy (Todorova, 2015). For instance, UAE is considered as the second largest desalinated water producer worldwide

${ }^{*}$ Corresponding author

E-mail: salmardeai@masdar.ac.ae

(C) 2016 International Association for Sharing Knowledge and Sustainability

DOI: $10.5383 /$ swes.8.01.007
(WWAP (World Water Assessment Programme), 2012). From this point, this study is examining the possibility of using sea water based bio-refinery system and studying the potentials of Avicennia marina as biomass for the production of valuable products, focusing on the economic feasibility of the process to UAE as well as worldwide.

\section{Materials and Method}

In this experiment Avicennia marina was used as substrate, seawater as media, and sludge inoculum. The sample was first characterized for TS, VS and ash content. Sample and seawater were both sampled from Ras Alkhaimah. The sludge was sampled from Al Wathba Wastewater treatment plant, Abu Dhabi. Seawater $\mathrm{pH}$ was measured using commercially available probes. Seawater salinity was determined drying a known mass of sample at $150^{\circ} \mathrm{C}$ and $570^{\circ} \mathrm{C}$, the weight of salt was then measured. The total solids (TS) and volatile solids (VS) of Avicennia marina and the sludge was determined at $150^{\circ} \mathrm{C}$ and $570^{\circ} \mathrm{C}$. 
Biomethane potential experiments were conducted at $37^{\circ} \mathrm{C}$ in serum bottles with $115 \mathrm{ml}$ liquid volume and $212 \mathrm{ml}$ headspace. The experiment was conducted using $1.09 \mathrm{~g}$ $\mathrm{gVSsalicornia} / \mathrm{gVSsediment}$ and an inoculum of $11.4 \mathrm{~g}$. Biomethane was measured by gas chromatography.

\section{Results and Discussion}

Seawater salinity was $43.2 \pm 0.1 \mathrm{~g} / \mathrm{kg}$ and a $\mathrm{pH}$ was 7.29 . The air-dry Avicennia marina $\mathrm{VS}$ was $0.77 \mathrm{gVS} / \mathrm{g}$ _original_sample and TS was $0.86 \mathrm{gTS} / \mathrm{g}$ _original_sample. The inoculum VS was $1.3 \pm 0.01 \mathrm{gVS} / \mathrm{g}$ _original_sample and the TS was 0.02 gTS/g_original_sample. Gas chromatography analysis had showed an increment in the biomethane production over an incubation period of initially forty eight days at $37^{\circ} \mathrm{C}$.

Figure 1 which shows the cumulative biomethane produced in this experiment. The experimented system showed the potential to be used for the production of biomethane as the readings showed increment in the biomethane production throughout incubation period. At day 48 the biomethane content has reached $52.8 \mathrm{mlCH}_{4} / \mathrm{gVS}$. Comparing these results with the theoretical value, $370 \mathrm{mlCH}_{4} / \mathrm{gVS}$, and then the low results can be due to the fact that the inoculum that has been used is not adapted to the high salinity in the seawater.

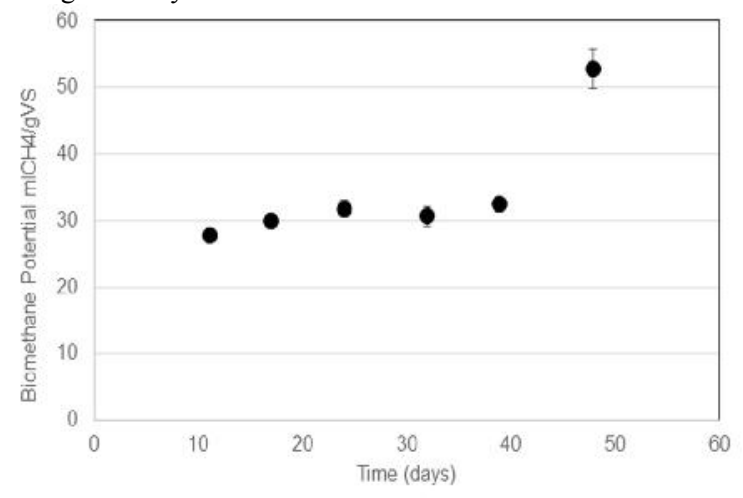

Figure 1 Biomethane Potential of Avicennia Marina at Seawater Conditions over an Incubation Period of 48 Days. Seawater, 43.2 G/Kg Salinity. The Substrate Over Inoculum Ratio Is 1.09gvsavicennia Marina /Gvsinuculm.
As per this study, the use of sea water is possible in the production of biomethane. This result will open new doors for very potential researches related to the biofuel and chemical production based on lignocellulosic biomass. The substitution of sea water instead of fresh water is economically and environmentally important since the consumption of water here in UAE is approximated to $550 \mathrm{~L}$ per individual per day which double the consumption of the global average which is around 250 L per individual per day ("Conserving every drop", 2014) and above of this, the demand for desalinating water is increasing. Start using seawater in different applications will minimize the risk of running out of water. The use of sea water in biorefinery systems will help in lowering down the production cost of the alternative energy, especially with the use of Avicennia marina as biomass since it is already adapted to UAE sea water salinity conditions opening new opportunities for research aiming for a better, cleaner and energy secured world.

\section{References}

[1] Conserving every drop. (2014). Retrieved from http://emsint.com/blog/conserving-every-drop/

[2] Dodd, R. S., Blasco, F., Rafii, Z. a., \& Torquebiau, E. (1999). Mangroves of the United Arab Emirates: Ecotypic diversity in cuticular waxes at the bioclimatic extreme. Aquatic Botany, 63(3-4), 291-304. http://doi.org/10.1016/S0304-3770(98)00124-7.

[3] Millero, F. J., Feistel, R., Wright, D. G., \& McDougall, T. J. (2008). The composition of Standard Seawater and the definition of the Reference-Composition Salinity Scale. Deep Sea Research Part I: Oceanographic Research Papers, 55(1), 50-72. http://doi.org/10.1016/j.dsr.2007.10.001.

[4] Sandilyan, S., \& Kathiresan, K. (2012). Mangrove conservation: a global perspective. Biodiversity and Conservation, 21(14), 3523-3542. http://doi.org/10.1007/s10531-012-0388-x.

[5] WWAP (World Water Assessment Programme). (2012). World Water Development Report Volume 4: Managing Water under Uncertainty and Risk (Vol. 1). Retrieved from http://www.unesco.org/new/fileadmin/MULTIMEDIA/H Q/SC/pdf/WWDR4 Volume 1-Managing Water under Uncertainty and Risk.pdf.

[6] Todorova, V. (2015, April 14). Pilot UAE desalination plants just months away from full operation. The National. Retrieved from http://www.thenational.ae/uae/environment/pilotuae-desalination-plants-just-months-away-from-fulloperation. 